\title{
Beneficial Effects of Rosmarinic Acid on IPEC-J2 Cells Exposed to the Combination of Deoxynivalenol and T-2 Toxin
}

\author{
Judit Mercédesz Pomothy $\mathbb{D D}^{1}{ }^{1}$ Réka Fanni Barna $\left(\mathbb{D},{ }^{1,2}\right.$ Erzsébet Anna Pászti, ${ }^{1}$ \\ Ákos Babiczky $\mathbb{D}^{3,4}$ Áron Szóládi, ${ }^{1}$ Ákos Jerzsele $\mathbb{D D}^{1}{ }^{1}$ and Erzsébet Pásztiné Gere $\mathbb{D}^{1}$ \\ ${ }^{1}$ Department of Pharmacology and Toxicology, University of Veterinary Medicine Budapest, H-1078 Budapest, Hungary \\ ${ }^{2}$ Department of Physiology and Biochemistry, University of Veterinary Medicine Budapest, H-1078 Budapest, Hungary \\ ${ }^{3}$ Neuronal Networks and Behaviour Research Group, Research Centre for Natural Sciences, H-1117 Budapest, Hungary \\ ${ }^{4}$ Faculty of Natural Science, Budapest University of Technology and Economics, H-1111 Budapest, Hungary
}

Correspondence should be addressed to Erzsébet Pásztiné Gere; gere.erzsebet@univet.hu

Received 6 August 2020; Revised 4 December 2020; Accepted 10 December 2020; Published 22 December 2020

Academic Editor: Helen C. Steel

Copyright (c) 2020 Judit Mercédesz Pomothy et al. This is an open access article distributed under the Creative Commons Attribution License, which permits unrestricted use, distribution, and reproduction in any medium, provided the original work is properly cited.

\begin{abstract}
Mycotoxin contamination in feedstuffs is a worldwide problem that causes serious health issues both in humans and animals, and it contributes to serious economic losses. Deoxynivalenol (DON) and T-2 toxin (T-2) are major trichothecene mycotoxins and are known to challenge mainly intestinal barrier functions. Polyphenolic rosmarinic acid (RA) appeared to have antioxidant and anti-inflammatory properties in vitro. The aim of this study was to investigate protective effects of RA against DON and T-2 or combined mycotoxin-induced intestinal damage in nontumorigenic porcine cell line, IPEC-J2. It was ascertained that simultaneous treatment of DON and T-2 (DT2: $1 \mu \mathrm{mol} / \mathrm{LDON}+5 \mathrm{nmol} / \mathrm{LT}-2)$ for $48 \mathrm{~h}$ and $72 \mathrm{~h}$ reduced transepithelial electrical resistance of cell monolayer, which was restored by $50 \mu \mathrm{mol} / \mathrm{L}$ RA application. It was also found that DT2 for $48 \mathrm{~h}$ and $72 \mathrm{~h}$ could induce oxidative stress and elevate interleukin-6 (IL-6) and interleukin-8 (IL-8) levels significantly, which were alleviated by the administration of RA. DT2 administration contributed to the redistribution of claudin-1; however, occludin membranous localization was not altered by combined mycotoxin treatment. In conclusion, beneficial effect of RA was exerted on DT2-deteriorated cell monolayer integrity and on the perturbated redox status of IPEC-J2 cells.
\end{abstract}

\section{Introduction}

Mycotoxins are secondary metabolites produced by various fungi. Human and farm animal exposure to Fusarium mycotoxins such as deoxynivalenol (DON) and T-2 toxin (T-2) could occur via feedstuff ingestion (Figures 1(a) and 1(b)).

The enterocytes serve as a pivotal barrier between the organism and numerous noxious stimuli. These cells absorb the nutrients and form a border against the pathogens and toxins and actively take part in the modulation of the immune functions of the gut [1]. The IPEC-J2 cell line model is a noncancerous, nontransformed cell model suitable for in vitro studying on interaction between xenobiotics such as lipopolysaccharide $[2,3]$ or mycotoxin $[4,5]$ and intestinal epithelium.
Several research groups reported that DON application results in significant reduction in transepithelial electrical resistance (TEER) values in a dose- and application routedependent manner [6-8]. T-2 could also decrease IPEC-J2 cell barrier integrity at $210 \mathrm{nmol} / \mathrm{L}$ for $72 \mathrm{~h} \mathrm{[7].}$

Adjacent enterocytes close their paracellular space around themselves with forming tight junctions (TJ). It was also investigated if there is a connection between mycotoxin contamination and expression of TJ proteins of intestinal cell monolayers. Zonula occludens- (ZO-) 1 expression was impacted differently when epithelial cells of porcine small intestinal origin were exposed to low or high concentrations of DON. Disintegration of ZO-1 was only observed when DON was used at $6.74 \mu \mathrm{mol} / \mathrm{L}$ [6]. Claudin-3 was detected as a continuous lining around each untreated IPEC-J2 cell, 


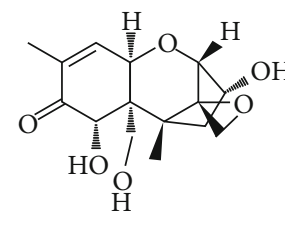

(a)

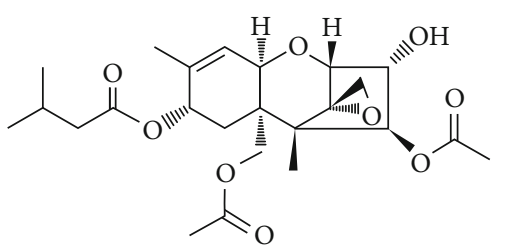

(b)<smiles>O=C(/C=C/c1ccc(O)c(O)c1)O[C@H](Cc1ccc(O)c(O)c1)C(=O)O</smiles>

(c)

Figure 1: Chemical structures of the tested food-borne compounds: (a) DON, (b) T-2 toxin, and (c) RA.

in contrast to DON-contaminated cells in which reduced expression of tight junctional protein, claudin-3 was seen [5]. Several papers focused on the elucidation of the correlation between DON application and decrease in protein expression of claudin-3 and claudin-4 in intestinal epithelial cells [9-11]; however, only one finding suggests that DON affects claudin- 1 expression at an elevated $20 \mu \mathrm{mol} / \mathrm{L}$ concentration [12]. Changes in occludin localization after DON administration have not been completely elucidated yet.

T-2 could influence transcript levels of claudin-3, claudin-4, and occludin in human epithelial (Caco-2) cells when this mycotoxin was applied in micromolar concentrations [13]. Hence, the effects of T-2 on the assembly of TJ proteins have not been clarified yet.

The effects of DON on the modulation of cytokine production have been reported mostly based on the changes in mRNA levels. Kang et al. [8] observed that in proinflammatory cytokine, interleukin- (IL-) 6 gene expression was significantly increased in IPEC-J2 cells exposed to DON at $0.5-2 \mu \mathrm{mol} / \mathrm{L}$ concentrations for $4 \mathrm{~h}$. In accordance, Liu et al. [14] reported that IL-6 mRNA abundances of IPEC$\mathrm{J} 2$ cells were elevated after $8 \mathrm{~h}$ incubation of cells with $4 \mu \mathrm{mol} / \mathrm{L}$ DON. Guo et al. [15] also found that that $24 \mathrm{~h}$ treatment of IPEC-J2 cells with $1 \mu \mathrm{mol} / \mathrm{L}$ DON led to the increase in IL-6 levels. However, there are controversial data regarding DON-induced mRNA abundances of IL-8 in IPEC-J2 cells. Liu et al. [14] found that DON at $4 \mu \mathrm{mol} / \mathrm{L}$ concentration for $8 \mathrm{~h}$ could not trigger significant alterations in gene expressions of IL-8; however, it could cause downregulation of IL-8 levels at $0.25 \mu \mathrm{mol} / \mathrm{L}$. It was also ascertained that higher concentrations of DON (at $6.7 \mu \mathrm{mol} / \mathrm{L}$ ) did not change the expressions of IL-8 mRNA in IPEC-J2 cells [16]. In contrast, Cano et al. [17] proved that $\mathrm{DON}$ at $10 \mu \mathrm{mol} / \mathrm{L}$ for $8 \mathrm{~h}$ significantly elevated the mRNA levels of IL-8. IL-8 production was also measured by Guo et al. [15], and it was reported that $1 \mu \mathrm{mol} / \mathrm{L}$ DON significantly increased IL-8 contents in IPEC-J2 with 24 and $48 \mathrm{~h}$ incubation time.

It is widely accepted that the toxicity of trichothecene mycotoxins is dominantly caused by oxidative stress. Inside the cells, DON and T-2 activated the mitogen activated protein kinases (MAPK) [18], Janus kinase/signal transducers, activators of transcription (JAK/STAT) [19], and nuclear factor-kappa B (NF- $\kappa$ B) [20] signaling pathways, which could lead to apoptosis. In addition to ribosomes, mitochondria are considered target to the trichothecene mycotoxin contaminations [21, 22]. Kang et al. [8] published that DON at $6.7 \mu \mathrm{mol} / \mathrm{L}$ in IPEC-J2 cells could cause significant elevations in intracellular ROS levels after $24 \mathrm{~h}$ mycotoxin exposure.

The polyphenolic compounds have protective properties against oxidative stress-related disorders. The phenolic compounds can be subdivided into flavonoids and nonflavonoid substances [23], and rosmarinic acid (RA) belongs to the nonflavonoid group (Figure 1(c)). The efficacy of RA in the inhibition of lipid peroxidation was reported by Fadel et al. [24]. RA is also capable of decreasing some of the proinflammatory cytokine production in vitro. Based on an auditory cell line, HEI-OC1 experimental data RA inhibited IL- 6 and IL- $1 \beta$ levels at 50 and $100 \mu \mathrm{mol} / \mathrm{L}$ concentrations on cadmium- $\left(\mathrm{Cd}^{2+}-\right)$ treated cells after $1 \mathrm{~h}$ of incubation [25]. Villalva et al. [26] found that RA-enriched extract to Caco-2 cells could reduce the secretions of IL- 6 , IL- $1 \beta$, and tumor necrosis factor- (TNF-) $\alpha$.

Humans and animals may be exposed simultaneously to different mycotoxins produced by Fusarium species. In our research, binary mixture of DON and T-2 was used (DT2) to assess toxicological effects of these fusariotoxins and to characterize putative preventive function of RA in the development of intestinal dysfunction in vitro.

The aims of our study were (i) to elucidate cytotoxicity of DON, T-2, DT2, and RA, (ii) to determine the impact of DT2 and RA on intestinal barrier integrity, and (iii) to assess IL-6- and IL-8-regulating and oxidative stressinducing properties of mycotoxin combination and RA using IPEC-J2 cells. Moreover, an immunofluorescent study was also performed to monitor the changes in localization pattern of two TJ proteins, occludin and claudin-1, in IPEC-J2 cells exposed to DT2 in the absence and in the presence of RA. 


\section{Materials and Methods}

2.1. Reagents. DON (molecular weight $296.319 \mathrm{~g} / \mathrm{mol}$ ), T-2 toxin $(466.527 \mathrm{~g} / \mathrm{mol})$, and RA $(360.31 \mathrm{~g} / \mathrm{mol})$ were purchased from Merck (Darmstadt, Germany). Dimethyl sulfoxide (DMSO) and acetonitrile were obtained from Thermo Fisher Scientific (Waltham, MA, USA). The final concentration of acetonitrile or DMSO in the cell culture medium was less than $0.5 \%(v / v)$.

2.2. Cell Culture. The porcine intestinal epithelial cell line, IPEC-J2 (ACC 701), was grown in 50\% Dulbecco's Modified Eagle's Medium (DMEM) and 50\% Ham's F12 Nutrient Mixture (Merck, Darmstadt, Germany) supplemented with $1.5 \mathrm{mmol} / \mathrm{L}$ HEPES, 5\% fetal bovine serum (Biocenter, Budapest, Hungary), 1\% insulin/transferrin/sodium selenite media supplement, $5 \mathrm{ng} / \mathrm{mL}$ epidermal growth factor, and $1 \%$ penicillin/streptomycin (all purchased from Invitrogen, Thermo Fisher Scientific, Waltham, MA, USA). The IPECJ2 cell line was obtained from Dr. Jody Gookin, Department of Clinical Sciences, College of Veterinary Medicine, North Carolina State University, Raleigh, NC, USA. Cells were used between passages 40 and 42 . Cells were maintained in $75 \mathrm{~cm}^{2}$ cell culture flasks with filter screw caps (Orange Scientific, Braine-l'Alleud, Belgium) at $37^{\circ} \mathrm{C}$ in a humidified atmosphere of $5 \% \mathrm{CO}_{2}$. Complete culture medium was changed every other day.

2.3. Exposure of IPEC-J2 Cells to Mycotoxins and RA. IPEC-J2 cells were treated with DON or T-2 both apically and basolaterally. DON in a concentration range of $0-50 \mu \mathrm{mol} / \mathrm{L}$ or T-2 in $0-50 \mathrm{nmol} / \mathrm{L}$ was used for $48 \mathrm{~h}$ and $72 \mathrm{~h}$.

For assessing the impact of mycotoxin combinations, the following mixtures were prepared and added both apically and basolaterally: $1 \mu \mathrm{mol} / \mathrm{L} \mathrm{DON}+5 \mathrm{nmol} / \mathrm{L} \mathrm{T}-2 ; 5 \mu \mathrm{mol} /$ $\mathrm{L} \mathrm{DON}+10 \mathrm{nmol} / \mathrm{L} \mathrm{T}-2 ; 10 \mu \mathrm{mol} / \mathrm{L} \mathrm{DON}+5 \mathrm{nmol} / \mathrm{L} \mathrm{T}-2$ ; and $10 \mu \mathrm{mol} / \mathrm{L} \mathrm{DON}+10 \mathrm{nmol} / \mathrm{L} \mathrm{T}-2$. Two incubation times were applied ( $48 \mathrm{~h}$ and $72 \mathrm{~h}$ ).

IPEC-J2 cells, which obtained antioxidant treatments, were preincubated with RA for $24 \mathrm{~h}$ at 50, 100, 500, and $1000 \mu \mathrm{mol} / \mathrm{L}$. RA was dissolved in culture medium with $5 \%$ DMSO. Dissolved substances were filtered with syringe filters (Millex-GV, pore size: $0.2 \mu \mathrm{m}$, Merck, Darmstadt, Germany) before application on the IPEC-J2 cells.

2.4. Evaluation of Cytotoxicity with Neutral Red Uptake Assay. Viability of IPEC-J2 cells was measured $48 \mathrm{~h}$ and $72 \mathrm{~h}$ after treatment with DON, T-2, DT2, and RA by neutral red (NR) uptake assay (Merck, Darmstadt, Germany). IPEC$\mathrm{J} 2$ cells were incubated with mycotoxins and RA for $48 \mathrm{~h}$ and $72 \mathrm{~h}$, respectively. The control cells were incubated only with phenol red-free DMEM. After the removal of the medium and washing, $45 \mathrm{mg} / \mathrm{L} \mathrm{NR}$ solution was added [27] to the IPEC-J2 cells in plain phenol red-free medium for $2 \mathrm{~h}$. After washing the IPEC-J2 cells, a destaining solution (ethanol/demineralized water/glacial acetic acid, 7.5/7.4/0.15, $v / v / v)$ was applied for $10 \mathrm{~min}$. The viability was measured at $540 \mathrm{~nm}$ using an ELISA Plate Reader (EZ Read Biochrom 400, Cambridge, UK).
2.5. Measurement of the Integrity of IPEC-J2 Cells. The measurement of TEER across epithelial monolayers is used to evaluate the integrity of the TJ barrier. IPEC-J2 cells were seeded on 6-well Transwell inserts (polyester, $0.4 \mu \mathrm{m}$ pore size, Corning, Merck, Darmstadt, Germany), and the seeding density was $1 \times 10^{6}$ cells/well. Barrier function was evaluated after the cells reached confluent state and was measured with EVOM (Epithelial Tissue Volt/Ohmmeter) (World Precision Instruments, Berlin, Germany). The results were calculated as $\mathrm{k} \Omega \mathrm{x} \mathrm{cm}^{2}$ by multiplying the values by the surface area of the monolayer $\left(4.67 \mathrm{~cm}^{2}\right)$.

2.6. Quantification of $\mathrm{H}_{2} \mathrm{O}_{2}$ Production. $\mathrm{H}_{2} \mathrm{O}_{2}$ production was monitored in IPEC-J2 cells by using the Amplex Red Hydrogen Peroxide Assay Kit (Invitrogen, Thermo Fisher Scientific, Waltham, MA, USA). In the presence of horseradish peroxidase, Amplex Red reagent reacts with $\mathrm{H}_{2} \mathrm{O}_{2}$ (in $1: 1$ stoichiometry) to produce a red fluorescent product called resorufin. After $48 \mathrm{~h}$ and $72 \mathrm{~h}$, cell-free supernatants were taken from the basolateral compartment and were used for further experiments. $50 \mu \mathrm{L}$ of the collected cell-free supernatant was mixed with $50 \mu \mathrm{L}$ of the Amplex Red working solution according to the manufacturer's instructions. The fluorescence intensities were measured with a fluorometer (Victor X2 2030, Perkin Elmer, Waltham, MA, USA) using $560 \mathrm{~nm}$ excitation and $590 \mathrm{~nm}$ emission wavelengths.

2.7. Determination of Proinflammatory Cytokines Expression. IL-6 and IL-8 levels were determined in IPEC-J2 cell-free supernatants using porcine IL-6 (Aviva System Biology, San Diego, USA) and IL-8 sandwich ELISA kits (Merck, Darmstadt, Germany). To elucidate the cytokine levels after $48 \mathrm{~h}$ and $72 \mathrm{~h}$ treatment, the supernatants were treated according to the manufacturer's instructions and measured with an EZ Read Biochrom 400 microplate reader (Biochrom, Cambridge, UK) at $450 \mathrm{~nm}$. Cytokine concentrations were calculated from the measured absorbance values and were expressed as means \pm SDs.

2.8. Localization of Occludin and Claudin-1 Distribution via Immunofluorescent Staining. The localization of claudin-1 and occludin was assessed by confocal microscopy. Confluent IPEC-J2 cells were incubated with DT2 or DT2 + RA added apically and basolaterally for $72 \mathrm{~h}$. Cells were fixed with 100\% methanol (Met-OH, Merck, Darmstadt, Germany) and stained on the membrane inserts.

IPEC-J2 cells were blocked for $20 \mathrm{~min}$ at room temperature in bovine serum albumin solution (phosphate-buffered saline (PBS) buffer supplemented with $5 \%$ bovine serum albumin (BSA, Merck, Darmstadt, Germany)). Sections were incubated for $1 \mathrm{~h}$ at room temperature in the presence of anti-claudin-1 rabbit polyclonal primary antibody $(1: 200$, Invitrogen, Thermo Fisher Scientific, Waltham, MA, USA) or anti-occludin rabbit polyclonal primary antibody $(1: 200$, Merck, Darmstadt, Germany). The antibodies were previously diluted in 5\% BSA solutions. Then the inserts were incubated with Alexa Fluor 546 conjugated anti-rabbit IgG secondary antibodies $(1: 200$, Invitrogen, Thermo Fisher Scientific, Waltham, MA, USA), which were diluted in PBS. The 


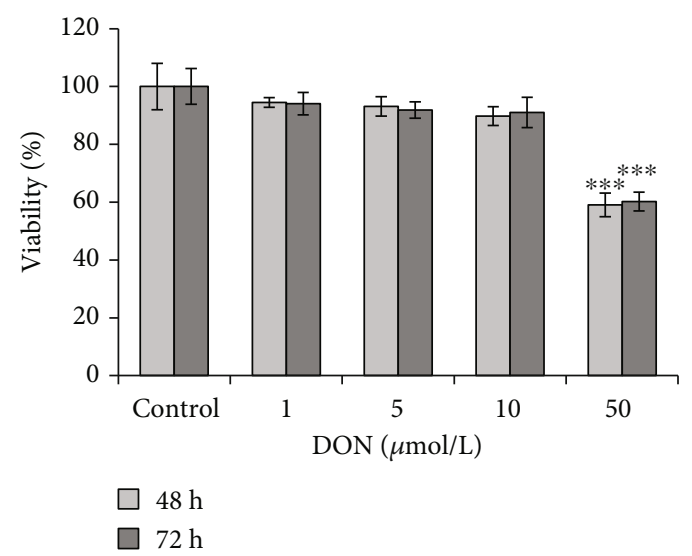

(a)

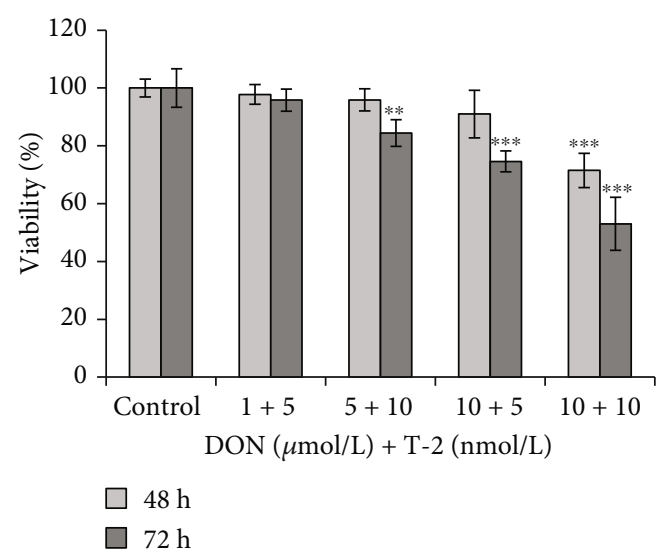

(c)

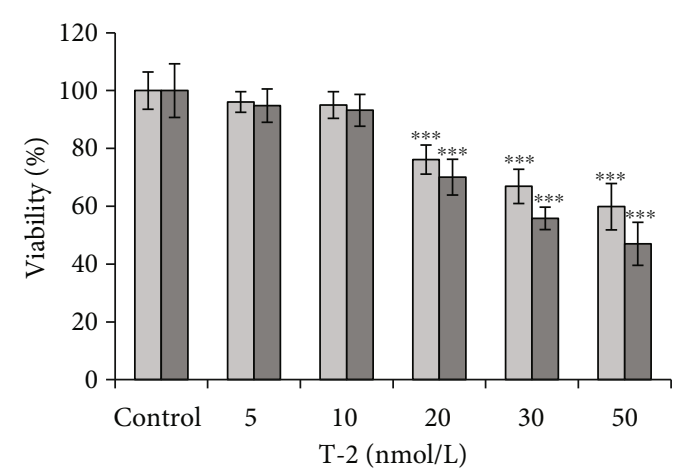

$\square 48 \mathrm{~h}$

$\square 72 \mathrm{~h}$

(b)

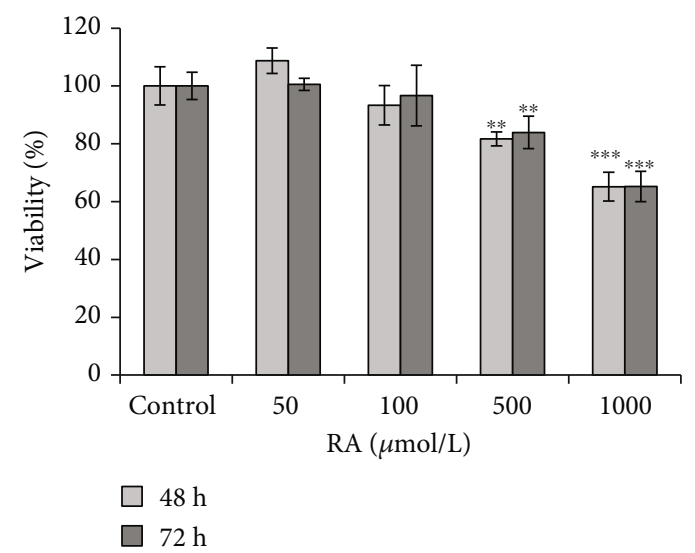

(d)

Figure 2: Effects of (a) DON, (b) T-2, (c) DT2, and (d) RA on viability \% of the differentiated IPEC-J2 cells measured by NR assay. Incubation times were $48 \mathrm{~h}$ and $72 \mathrm{~h}$. Significant differences were found between untreated samples and cells exposed to $50 \mu \mathrm{mol} / \mathrm{L} \mathrm{DON} \mathrm{or} 20 \mathrm{nmol} / \mathrm{L}$ T2. In the case of DT2 treatment, addition of $1 \mu \mathrm{mol} / \mathrm{L}$ DON and $5 \mathrm{nmol} / \mathrm{L} \mathrm{T}-2$ to IPEC-J2 cells did not influence cell viability significantly for $48 \mathrm{~h}$ and $72 \mathrm{~h}$. RA appeared to be cytotoxic at higher concentrations (at 500 and at $1000 \mu \mathrm{mol} / \mathrm{L}$ ). Data are presented as viability\%means \pm SDs $(n=8, * * p<0.01$ and $* * * p<0.001)$.

sialic acid residues in IPEC-J2 cell membrane were stained with wheat germ agglutinin conjugated with Alexa Fluor 488 ( $1: 200$ diluted in PBS, WGA Alexa Fluor 488, Invitrogen, Thermo Fisher Scientific, Waltham, MA, USA) for $10 \mathrm{~min}$, and cell nuclei were stained in blue using 4',6-diamidino-2-phenylindole (DAPI) (1:500 diluted in PBS, Invitrogen, Thermo Fisher Scientific, Waltham, MA, USA) for an additional $10 \mathrm{~min}$.

Between incubations, the inserts were washed in PBS for $3 \times 5 \mathrm{~min}$. Inserts were attached on glass slides using fluorescent mounting medium (Dako, Agilent Technologies, Glostrup, Denmark). The claudin-1 samples were analyzed using a Zeiss confocal microscope 63x Plan Apochromat 63x/1.4 Oil DIC M27 (Zeiss LSM 710 Confocal Microscope, Oberkochen, Germany) while the occludin localization was detected with Leica confocal microscope; lenses were 63x/1.4 Oil (Leica SP2 Confocal Microscope, Wetzlar, Germany).

2.9. Statistical Analysis. The statistical analysis of the results was performed by using the R Core Team (2016) (R: A language and environment for statistical computing (R Foundation for Statistical Computing, Vienna, Austria)). Differences between groups were analyzed by one-way ANOVA coupled with the post hoc Tukey test for multiple comparisons, where data were of normal distribution and homogeneity of variances was confirmed. $* p<0.05 ; * * p<0.01$, and $* * * p<$ 0.001 were considered statistically significant.

\section{Results}

3.1. Cytotoxicity of DON, T-2, DT2, and RA. The cytotoxic effects of DON, T-2, DT2, and RA on IPEC-J2 cells were evaluated over $48 \mathrm{~h}$ and $72 \mathrm{~h}$ (Figure 2). DON and T-2 were applied in a concentration range of $0-50 \mu \mathrm{mol} / \mathrm{L}$ and $0-$ $50 \mathrm{nmol} / \mathrm{L}$, respectively. Significant cell death was observed upon exposure of cells to DON at $50 \mu \mathrm{mol} / \mathrm{L}$ after $48 \mathrm{~h}$ and $72 \mathrm{~h}$ incubation $(p<0.001)$ (Figure $2(\mathrm{a}))$. T-2 showed cytotoxic effects at $20 \mathrm{nmol} / \mathrm{L}$ and at higher concentrations after $48 \mathrm{~h}$ and $72 \mathrm{~h}$ treatments $(p<0.001)$ (Figure $2(\mathrm{~b}))$. Mycotoxin combination (DT2) was also tested (Figure 2(c)). It was found that when IPEC-J2 cells were treated with DON and T-2 simultaneously, the $5 \mu \mathrm{mol} / \mathrm{L} \mathrm{DON}+10 \mathrm{nmol} / \mathrm{L} \mathrm{T}$ $-2,10 \mu \mathrm{mol} / \mathrm{L} \mathrm{DON}+5 \mathrm{nmol} / \mathrm{L} \mathrm{T}-2$, and $10 \mu \mathrm{mol} / \mathrm{L} \mathrm{DON}$ $+10 \mathrm{nmol} / \mathrm{L} \mathrm{T}-2$ treatments were toxic to the cells 


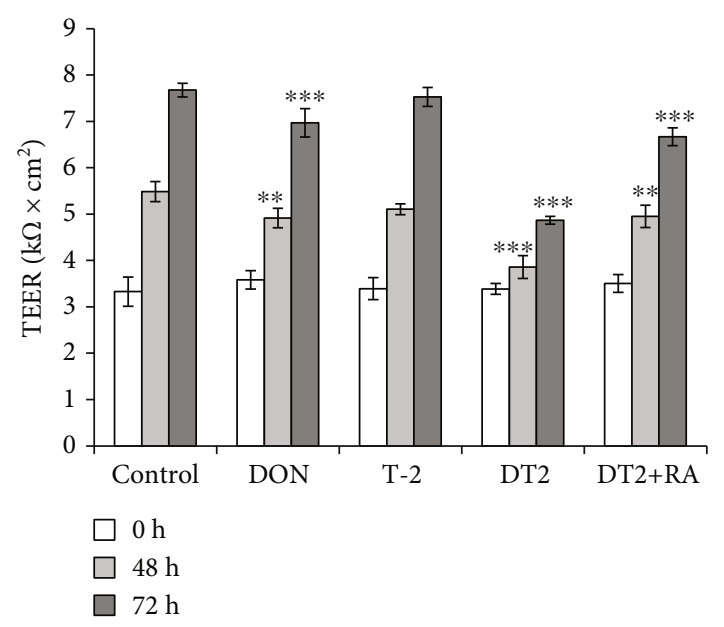

FIGURE 3: Transepithelial electrical resistance (TEER) measurements of IPEC-J2 monolayers. Cells were incubated with $1 \mu \mathrm{mol} / \mathrm{L}$ DON, with $5 \mathrm{nmol} / \mathrm{L} \mathrm{T}-2$, with DT2 $(1 \mu \mathrm{mol} / \mathrm{L} \mathrm{DON}+5 \mathrm{nmol} / \mathrm{L} \mathrm{T}-2)$, and with $\mathrm{DT} 2+\mathrm{RA}(1 \mu \mathrm{mol} / \mathrm{L} \mathrm{DON}+5 \mathrm{nmol} / \mathrm{L} \mathrm{T}-2+50 \mu \mathrm{mol} / \mathrm{L} \mathrm{RA})(24 \mathrm{~h}$ preincubation) for $48 \mathrm{~h}$ and $72 \mathrm{~h}$. TEER values are expressed in $\mathrm{k} \Omega \times$ $\mathrm{cm}^{2} . * * p<0.01$ and $* * * p<0.001$ compared to the control values. Data are presented as TEER means \pm SDs $(n=9)$.

significantly after $72 \mathrm{~h}$ incubation $(p<0.01$ and $p<0.001)$. The effect of RA on cell viability was tested in concentration range of 50-1000 $\mu \mathrm{mol} / \mathrm{L}$ (Figure 2(d)). Treatment with RA at 500 and $1000 \mu \mathrm{mol} / \mathrm{L}$ significantly decreased cell viability after $48 \mathrm{~h}$ and $72 \mathrm{~h}$ exposure $(p<0.01$ and $p<0.001)$; however, RA did not deteriorate cell viability at lower concentrations $(50$ and $100 \mu \mathrm{mol} / \mathrm{L})$. For further investigations, we applied the noncytotoxic $1 \mu \mathrm{mol} / \mathrm{L} \mathrm{DON}+5 \mathrm{nmol} / \mathrm{L} \mathrm{T}-2$ mycotoxin combination and RA at $50 \mu \mathrm{mol} / \mathrm{L}$.

3.2. Cell Membrane Integrity Changes after Mycotoxin and RA Exposure. To determine the barrier disrupting effects of DON, T-2, and DT2 and the putative barrier-reinforcing effect of RA, TEER measurements were carried out using $48 \mathrm{~h}$ and $72 \mathrm{~h}$ treatment times (Figure 3). Incubation of cells with $5 \mathrm{nmol} / \mathrm{L} \mathrm{T}-2$ did not alter TEERs of cell monolayers, but $48 \mathrm{~h}$ DON and DT2 administration caused significant decrease in TEER values $(p=0.003$ and $p<0.001)$. TEERs of IPEC-J2 cells treated with DT2 $+50 \mu \mathrm{mol} / \mathrm{L}$ RA showed lower TEERs compared to those of controls $(p=0.006)$, but they were significantly elevated to decreased TEERs of DT2-treated samples $(p<0.001)$ after $48 \mathrm{~h}$ exposure. The detrimental effect of DT2 could be suppressed partially with the application of RA after $48 \mathrm{~h}$ and $72 \mathrm{~h}$.

3.3. Changes in Extracellular $\mathrm{H}_{2} \mathrm{O}_{2}$ Production after Mycotoxin and RA Treatments. The effect of the DON, T-2, DT2, and RA treatments on the extracellular $\mathrm{H}_{2} \mathrm{O}_{2}$ production of the IPEC-J2 cells was determined. The cell-free supernatants were collected after $48 \mathrm{~h}$ and $72 \mathrm{~h}$ (Figure 4 ). Based on the results, after $48 \mathrm{~h}$ incubation of cells with $1 \mu \mathrm{mol} / \mathrm{L}$ DON and DT2, the extracellular $\mathrm{H}_{2} \mathrm{O}_{2}$ levels were significantly increased (in each case $p<0.001$ ). When DT2-treated samples were compared with those exposed to DT2 + RA, significant differences were measured $(p<0.001)$. The $\mathrm{H}_{2} \mathrm{O}_{2}$

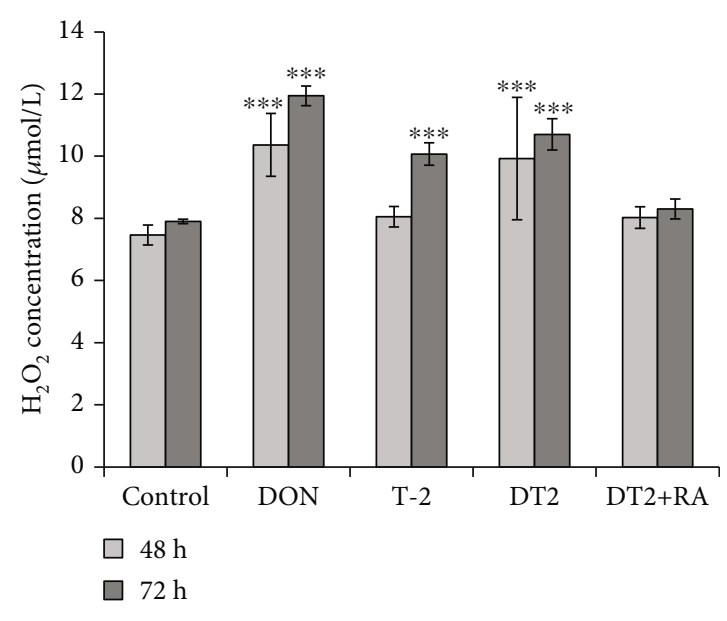

FIgURE 4: The changes of $\mathrm{H}_{2} \mathrm{O}_{2}$ production after incubation of IPEC-J2 cells with $1 \mu \mathrm{mol} / \mathrm{L}$ DON, $5 \mathrm{nmol} / \mathrm{L}$ T-2, DT2 $(1 \mu \mathrm{mol} / \mathrm{L} \mathrm{DON}+5 \mathrm{nmol} / \mathrm{L} \mathrm{T}-2), \quad$ and $\mathrm{DT} 2+\mathrm{RA}$ $(1 \mu \mathrm{mol} / \mathrm{L} \mathrm{DON}+5 \mathrm{nmol} / \mathrm{L} \mathrm{T}-2+50 \mu \mathrm{mol} / \mathrm{L} \mathrm{RA})(24 \mathrm{~h}$ preincubation) for indicated time periods ( $48 \mathrm{~h}$ and $72 \mathrm{~h}$ ). $* * * p<0.001$ compared to the control values. Data are presented as means $\pm \mathrm{SD}(n=8)$.

contents produced by DT2 + RA-treated IPEC-J2 cells did not differ from the $\mathrm{H}_{2} \mathrm{O}_{2}$ levels from control cells. DON, T2 , and DT2 induced significant increase in extracellular $\mathrm{H}_{2} \mathrm{O}_{2}$ levels after $72 \mathrm{~h}$ treatment. DT2-caused oxidative stress could be quenched effectively with the pretreatment of cells with RA at $50 \mu \mathrm{mol} / \mathrm{L}$ for $24 \mathrm{~h}(p<0.001)$.

3.4. The Effect of DT2 and RA on IL-6 and IL-8 Levels. The IL6 levels (Figure 5(a)) were elevated after DT2 $(p<0.001)$ exposure, and overproduction was completely inhibited by DT2 + RA treatments for $48 \mathrm{~h}$ and $72 \mathrm{~h}$. There were no significant differences in IL-6 levels between control samples and the DT2 + RA-treated cells $(p=0.145,48 \mathrm{~h}$, and $p=0.711$, $72 \mathrm{~h}$ ). The IL-8 levels (Figure 5(b)) were also increased significantly in DT2-treated IPEC-J2 cells using $48 \mathrm{~h}$ and $72 \mathrm{~h}$ incubation times (both $p<0.001$ ). DT2 + RA at $50 \mu \mathrm{mol} / \mathrm{L}$ could stabilize perturbed IL-8 levels triggered by application of DT2. There were no significant differences in IL-8 levels between RA-protected DT2 samples and control-treated cells $(p=0.256,48 \mathrm{~h}$, and $p=0.368,72 \mathrm{~h})$.

3.5. Cellular Distribution of Claudin-1 and Occludin in IPECJ2 Cells Exposed to DT2 and RA. Localization of claudin-1 (Figures 6(a)-6(c)) and occludin (Figures 6(d)-6(f)) in TJ assembly was assessed in untreated control and in DT2treated IPEC-J2 cells using immunofluorescence staining. The cells were investigated $72 \mathrm{~h}$ after DT2 and DT2 +RA treatments. The localization pattern of claudin-1 significantly changed when DT2 was continuously administered. The loss of membranous claudin-1 proteins from TJ was observed in the form of discontinuous membrane pattern in contrast to the distribution of those in control cells (Figures 6(a) and 6(b)). This phenomenon might explain TEER changes observed when DT2 was administered to the IPEC-J2 cells for $72 \mathrm{~h}$. 


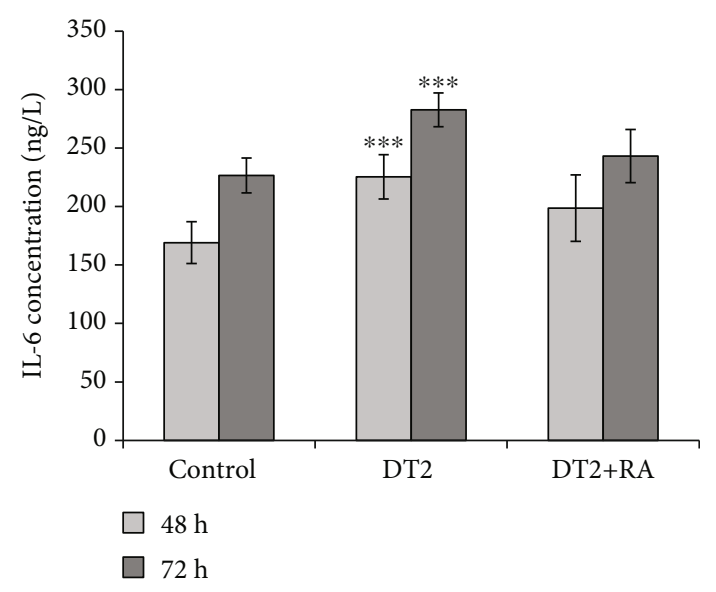

(a)

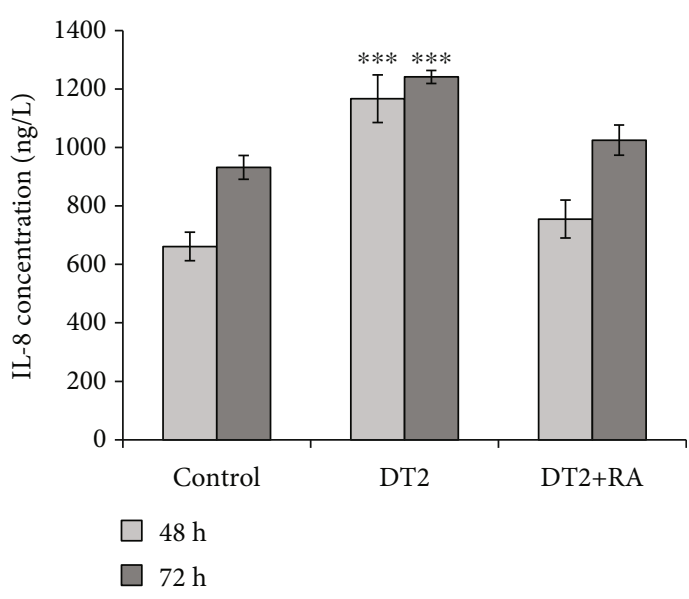

(b)

FIgURE 5: Measured changes of (a) IL-6 and (b) IL-8 of IPEC-J2 cells. The cytokine concentrations (ng/L) in the cell-free supernatants were calculated using porcine sandwich ELISA kits. Cells were treated with DT2 $(1 \mu \mathrm{mol} / \mathrm{LDON}+5 \mathrm{nmol} / \mathrm{LT}-2)$ and DT2 + RA $(1 \mu \mathrm{mol} / \mathrm{L} \mathrm{DON}+5 \mathrm{nmol} / \mathrm{L} \mathrm{T}-2+50 \mu \mathrm{mol} / \mathrm{LRA})(24 \mathrm{~h}$ preincubation) for $48 \mathrm{~h}$ and $72 \mathrm{~h} . * * * p<0.001$ compared to the control values. Data are presented as means $\pm \mathrm{SD}(n=10)$.

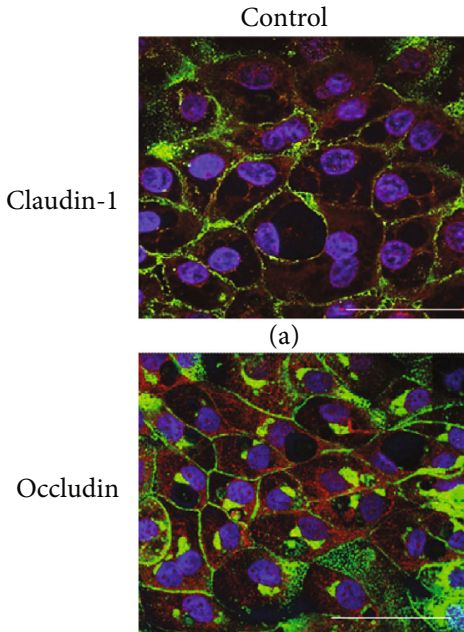

(d)

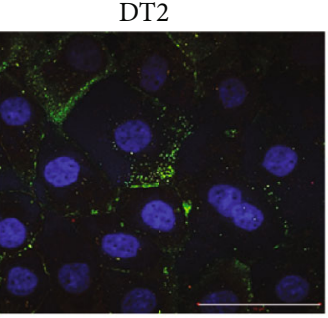

(b)

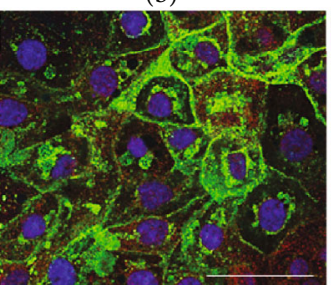

(e)

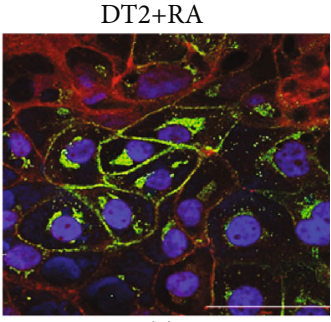

(c)

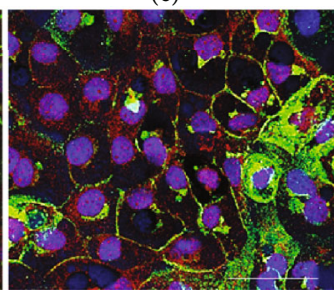

(f)

FIgURE 6: Effects of DT2 and DT2 + RA (RA pretreatment for $24 \mathrm{~h}$ ) on the localization pattern of (a-c) claudin-1 and (d-f) occludin using immunofluorescent staining. Differentiated IPEC-J2 cells were cultured on membrane inserts for 10 days then were exposed to DT2 $(1 \mu \mathrm{mol} / \mathrm{L} \mathrm{DON}+5 \mathrm{nmol} / \mathrm{L} \mathrm{T}-2)$ or to DT2 $+\mathrm{RA}(1 \mu \mathrm{mol} / \mathrm{L} \mathrm{DON}+5 \mathrm{nmol} / \mathrm{L} \mathrm{T}-2+50 \mu \mathrm{mol} / \mathrm{L} \mathrm{RA})$; both treatments were applied apically and basolaterally for $72 \mathrm{~h}$. Cells were stained for occludin and claudin-1 (Alexa Fluor 546, red). Cell nuclei were stained with DAPI (blue), and cell membranes were labelled with wheat germ agglutinin (Alexa Fluor 488, green). In controls and in DT2 + RAtreated samples, claudin-1 and occludin were colocalized with wheat germ agglutinin. White scale bar shows $50 \mu \mathrm{m}$.

In controls, occludin localized in membranes of polarized IPEC-J2 cells (Figure 6(d)) and when cells were exposed to DT2 $(1 \mu \mathrm{mol} / \mathrm{L} \mathrm{DON}+5 \mathrm{nmol} / \mathrm{L} \mathrm{T}-2)$, occludin maintained cell membranous presence (Figure 6(e)). RA given simultaneously with DT2 seemed to preserve the integrity of the TJ protein assembly by maintaining the belt-like structures of occludin and claudin-1 (Figures 6(c) and 6(f)). DT2 + RA treatment $(1 \mu \mathrm{mol} / \mathrm{L} \mathrm{DON}+5 \mathrm{nmol} / \mathrm{L} \mathrm{T}-2+50 \mu \mathrm{mol} / \mathrm{L} \mathrm{RA})$ resulted in similar continuous lining of occludin and claudin-1 around each cell, similarly to that detected in untreated cells.

\section{Discussion}

Due to the natural cooccurrence of fusariotoxins in food and in feedstuffs, the toxicological evaluation of the impact of combined mycotoxins on gut barrier appeared to be of key importance. Most of the studies focus on separately added mycotoxin; however, in vitro interaction exists between fusariotoxins in terms of cell viability [28].

In our study, the DON and T-2 binary combination was firstly used on the porcine nontumorigenic nontransformed jejunal epithelial cells to elucidate the impact of 
these two trichothecene mycotoxins on barrier integrity of IPEC-J2 cell monolayers cultured on permeable support membranes. Until now only a few in vitro models have been used to perform risk assessments in the case of cooccurrence of DON and T-2 mycotoxins. Lei et al. [29] found that treatment with $\operatorname{DON}(2.696 \mu \mathrm{mol} / \mathrm{L})$ and $\mathrm{T}-2$ $(21.4 \mathrm{nmol} / \mathrm{L})$ increased oxidative stress thus inducing apoptosis in culture models, in chondrocytes and hepatic/tubular epithelial cell lines. Ruiz et al. [30, 31] examined the impact of DON and T-2 mycotoxin combination on immortalized hamster ovarian cells (CHO-K1) and on mammalian kidney epithelial (Vero) cell lines, and it was found that they acted antagonistically at $24 \mathrm{~h}, 48 \mathrm{~h}$, and $72 \mathrm{~h}$ of exposure. In contrast, Ficheux et al. [32] concluded that the toxicity of combination was greater than the individual toxicity of each mycotoxin in the case of DON and T-2 applied for 14 days on white blood cells progenitor cells, colony-forming unit of granulocyte/monocyte (CFU-GM). Additive effect of DON and T-2 on inhibition of platelet aggregation was reported possibly via similar biochemical mechanisms, when porcine platelet suspensions were exposed to this mycotoxin combination [33].

Cell viability assays can be used for better in vitro toxicological evaluation of the harmful effects of DON and T-2 and their combinations. Goossens et al. [7] determined the ratio of viable, apoptotic, and necrotic cells after incubation of IPEC-J2 cells with different concentrations of DON and T2 for $72 \mathrm{~h}$ using flow cytometric technique. $\mathrm{IC}_{50}$ values for DON were $23.5 \mu \mathrm{mol} / \mathrm{L}$ and $20.4 \mathrm{nmol} / \mathrm{L}$ for T-2 [7], respectively; therefore, decrease in TEER might be correlated with the cytotoxic effects of mycotoxins. Springler et al. [12] performed NR assay and lactate dehydrogenase ( $\mathrm{LDH}$ ) test for establishing the effect of DON on the viability of differentiated IPEC-J2 cells. It was found that DON could reduce significantly cell viability at $50 \mu \mathrm{mol} / \mathrm{L}$ after $24 \mathrm{~h}$ exposure using NR assays, and LDH test could detect $33 \%$ change in cell viability after $48 \mathrm{~h}$ incubation of IPEC-J2 cells with DON. Vandenbroucke et al. [34] reported that undifferentiated and differentiated IPEC-J2 cells have different sensitivities to DON contamination. In case of nonpolarized IPEC-J2, cell death was significant upon $24 \mathrm{~h}$ addition of DON at as low as $0.8425-33.7 \mu \mathrm{mol} / \mathrm{L}$ concentrations. In contrast, differentiated IPEC-J2 maintained viability in this concentration range; however, DON could induce significant reduction in TEER of cell monolayers. T-2 toxicity was evaluated by Verbrugghe et al. [35], and it was confirmed that $\mathrm{IC}_{50}$ values of T-2 mycotoxin for undifferentiated and differentiated IPEC-J2 cells were $12.198 \mathrm{nmol} / \mathrm{L}$ and $395.9 \mathrm{nmol} / \mathrm{L}$, respectively. In our work, we found firstly that DT2 combination did not affect IPEC-J2 cell viability at $1 \mu \mathrm{mol} / \mathrm{LDON}+5$ $\mathrm{nmol} / \mathrm{L} \mathrm{T}-2$ concentration after $72 \mathrm{~h}$ exposure.

It was also reported that the addition of $\mathrm{DON}$ at $3.37 \mu \mathrm{mol} / \mathrm{L}$ and T-2 at $21.4 \mathrm{nmol} / \mathrm{L}$ concentration for $72 \mathrm{~h}$ decreased TEER in a time- and concentration-dependent manner, and when the cells were incubated with cytotoxic concentrations of these mycotoxins, increased passage of doxycycline and paromomycin was measured across the IPEC-J2 cell monolayer [7]. Basolateral application of DON at $6.74 \mu \mathrm{mol} / \mathrm{L}$ caused significant decrease in TEER of IPEC-J2 cell monolayers after $24 \mathrm{~h}$ exposure [5]. In accordance with this, Springler et al. [12] confirmed that DON reduced TEER significantly at 5-20 $\mu \mathrm{mol} / \mathrm{L}$ after $24 \mathrm{~h}$ incubation. It is widely accepted that T-2 contamination can cause pathological gut lesions, but only few scientific data available for assessing the underlying mechanisms in the background of nanomolar T-2-related barrier dysfunction. The presence of T-2 contamination triggered transepithelial passage of Salmonella typhimurium across IPEC-J2 cell monolayers, which was proven by application of T-2 in lower concentration range of $1.6-10.5 \mathrm{nmol} / \mathrm{L}$ without detecting changes in TEER values after $24 \mathrm{~h}$ incubation [36]. In this work, we firstly reported that DT2 induced a significant decrease in TEERs of IPEC-J2 cell monolayers exposed to binary mixture of DT2 for $48 \mathrm{~h}$ and $72 \mathrm{~h}$, which could be compensated partially by application of RA at $50 \mu \mathrm{mol} / \mathrm{L}$. Vergauwen et al. [37] concluded that preincubation of cells with 200, 400 , and $600 \mu \mathrm{mol} / \mathrm{L}$ RA for $18 \mathrm{~h}$ could reinforce the IPEC-J2 cell monolayer integrity after peroxide challenge. This is in good agreement with our data as RA could also play a key role in strengthening the IPEC-J2 monolayer barrier integrity after exposure to binary mixture of fusariotoxins DT2 in our study.

The overproduction of cytokines plays a key defensive role in innate immune responses against noxious stimuli in epithelial cells $[38,39]$. Wan et al. [40] reported that DON caused elevations in relative abundances of IL-6 and IL-8 in IPEC-J2 cells exposed to $0.5-2 \mu \mathrm{mol} / \mathrm{L}$ DON for $48 \mathrm{~h}$. The impact of T-2 on cytokine levels in intestinal epithelial cells has not been widely studied yet. T-2 applied in concentration range of 4.29-275 $\mathrm{nmol} / \mathrm{L}$ appeared to upregulate IL-8 levels in Caco- 2 cells after $20 \mathrm{~h}$ exposure [41]. In accordance with these results, we found that IL- 6 and IL- 8 overproduction occurred when IPEC-J2 cells were incubated with DT2 combination for $48 \mathrm{~h}$ and $72 \mathrm{~h}$. In our study, these elevations in IL-6 and IL-8 levels were prevented with pretreatment of cells with $50 \mu \mathrm{mol} / \mathrm{L}$ concentration of RA for $24 \mathrm{~h}$.

The mode of action of DON and T-2 involves the induction of oxidative stress, which might suggest the beneficial role of plant-derived polyphenolic compounds such as RA in the prevention of fusariotoxin-induced intestinal damage. Recent in vivo studies have shown that dietary flavonoid supplementation in pig feed could reduce oxidative stress and inflammation, and thus, it could improve the overall performances of the pigs [42-44]. Zha et al. [43] proved that administration of flavone-type baicalin with copper could maintain optimal growth and increase antioxidant capacity in piglets fed with DON-contaminated feeds. Baicalin zinc supplementation could also restore DON-triggered impairment in nutrient absorption and provide antioxidant defense against excessive oxidative stress [44]. Antioxidant properties of RA with similar structural polyphenolic backbone were previously proven in in vitro and in situ experiments. Vergauwen et al. [37] carried out experiments with IPEC-J2 cells using various concentrations of RA, and it was confirmed that RA at higher concentrations $(200,400$, and $600 \mu \mathrm{mol} / \mathrm{L})$ could reduce intracellular ROS. In our study, we proved that extracellular $\mathrm{H}_{2} \mathrm{O}_{2}$ levels were successfully quenched by 
preincubation of RA at $50 \mu \mathrm{mol} / \mathrm{L}$ in IPEC-J2 cells treated with DT2.

There have been several studies involving the impact of fusariotoxins on localization or expression of TJ proteins. Untreated IPEC-J2 cells showed homogenous, intense membranous occludin and claudin-1 positivity. Springler et al. [12] reported that DON did not affect occludin and claudin- 4 levels at $20 \mu \mathrm{mol} / \mathrm{L}$ for $72 \mathrm{~h}$, but it significantly reduced claudin-1 and claudin-3. This observation is in contrast to that of $\mathrm{Gu}$ et al. [45], since they reported that lower concentration of DON $(6.74 \mu \mathrm{mol} / \mathrm{L})$ for $48 \mathrm{~h}$ could decrease occludin expression. However, until now, there have not been any documented data considering the impact of DT2 on the localization pattern of TJ proteins such as occludin and claudin-1 in IPEC-J2 cells. Based on our immunofluorescent findings, DT2 applied for $72 \mathrm{~h}$ did not alter occludin localization pattern; however, claudin-1 was lost from cell membrane observed as disruption in continuous lining of claudin-1 in cell membrane. Occludin appears to be one of the key constituents of TJ assembly; however, the formation of TJ does not only depend on occludin itself as it was proven by Suzuki [46]. Thereby, it can be assumed that changes in TEER induced by DT2 treatment can at least partially be correlated with relative claudin- 1 absence from TJ strands. Qiang [47] reported that RA at $50 \mu \mathrm{mol} / \mathrm{L}$ upregulated the mRNA expressions of ZO-1, ZO-2, claudin-1, and occludin in Caco-2 cells. It is in good agreement with our findings that RA could promote the membranous presence of claudin-1 in IPEC-J2 cells which were exposed to DT2.

\section{Conclusions}

In conclusion, this study demonstrated that binary mixture of DT2 at noncytotoxic concentrations could deteriorate barrier integrity of IPEC-J2 cells, and it could elevate the levels of inflammatory IL-6 and IL-8. These harmful effects could be alleviated by $24 \mathrm{~h}$ preadministration of polyphenolic RA. It was also shown that DT2-promoted oxidative stress could be effectively quenched by RA application. Moreover, changes in protein $\mathrm{TJ}$ assembly including claudin-1 redistribution were detected in DT2-treated cells which could be restored by RA addition. Therefore, RA appeared to have anti-inflammatory, antioxidant, and barrier-reinforcing potential in the prevention of DT2-caused detrimental intestinal effects in vitro.

\section{Data Availability}

The data used to support the findings of this study are available from the corresponding author upon request.

\section{Conflicts of Interest}

The authors declare that there is no conflict of interest regarding the publication of this paper.

\section{Acknowledgments}

This work was supported by the Hungarian National Research, Development and Innovation Office under grant numbers 115685 and 124522 and by the European Union and co-financed by the European Social Fund (EFOP-3.6.116-2016-00024; EFOP-3.6.2-16-2017-00012; and EFOP3.6.3-VEKOP-16-2017-00005). This project was supported by the János Bolyai Research Scholarship of the Hungarian Academy of Sciences and by the ÚNKP-20-5 New National Excellence Program of the Ministry for Innovation and Technology from the source of the National Research, Development and Innovation Fund. Special thanks are due to Dr. Bence Rácz and to Júlia Seprődi for providing confocal microscopic and chemical background.

\section{References}

[1] N. Miron and V. Cristea, "Enterocytes: active cells in tolerance to food and microbial antigens in the gut," Clinical and Experimental Immunology, vol. 167, no. 3, pp. 405-412, 2012.

[2] O. Farkas, G. Mátis, E. Pászti-Gere et al., "Effects of lactobacillus plantarum 2142 and sodium n-butyrate in lipopolysaccharide-triggered inflammation: comparison of a porcine intestinal epithelial cell line and primary hepatocyte monocultures with a porcine enterohepatic co-culture system12," Journal of Animal Science, vol. 92, no. 9, pp. 3835$3845,2014$.

[3] O. Palócz, E. Pászti-Gere, P. Gálfi, and O. Farkas, "Chlorogenic acid combined with lactobacillus plantarum 2142 reduced LPS-induced intestinal inflammation and oxidative stress in IPEC-J2 cells," PLoS One, vol. 11, no. 11, article e0166642, 2016.

[4] W. A. Awad, J. R. Aschenbach, and J. Zentek, "Cytotoxicity and metabolic stress induced by deoxynivalenol in the porcine intestinal IPEC-J2 cell line," Journal of Animal Physiology and Animal Nutrition, vol. 96, no. 4, pp. 709-716, 2012.

[5] A.-K. Diesing, C. Nossol, P. Panther et al., "Mycotoxin deoxynivalenol (DON) mediates biphasic cellular response in intestinal porcine epithelial cell lines IPEC-1 and IPEC-J2," Toxicology Letters, vol. 200, no. 1-2, pp. 8-18, 2011.

[6] A.-K. Diesing, C. Nossol, S. Dänicke et al., "Vulnerability of polarised intestinal porcine epithelial cells to mycotoxin deoxynivalenol depends on the route of application," PLoS One, vol. 6, no. 2, article e17472, 2011.

[7] J. Goossens, F. Pasmans, E. Verbrugghe et al., "Porcine intestinal epithelial barrier disruption by the Fusarium mycotoxins deoxynivalenol and T-2 toxin promotes transepithelial passage of doxycycline and paromomycin," BMC Veterinary Research, vol. 8, no. 1, p. 245, 2012.

[8] R. Kang, R. Li, P. Dai, Z. Li, Y. Li, and C. Li, "Deoxynivalenol induced apoptosis and inflammation of IPEC-J2 cells by promoting ROS production," Environmental Pollution, vol. 251, pp. 689-698, 2019.

[9] M. J. Gu, S. K. Song, S. M. Park, I. K. Lee, and C.-H. Yun, "Bacillus subtilis protects porcine intestinal barrier from deoxynivalenol via improved zonula occludens-1 expression," Asian-Australasian Journal of AnimalSciences, vol. 27, no. 4, pp. 580-586, 2014.

[10] K.-H. Ling, M. L. Y. Wan, H. El-Nezami, and M. Wang, "Protective capacity of resveratrol, a natural polyphenolic 
compound, against deoxynivalenol-induced intestinal barrier dysfunction and bacterial translocation," Chemical Research in Toxicology, vol. 29, no. 5, pp. 823-833, 2016.

[11] P. Pinton, J.-P. Nougayrède, J.-C. del Rio et al., "The food contaminant deoxynivalenol, decreases intestinal barrier permeability and reduces claudin expression," Toxicology and Applied Pharmacology, vol. 237, no. 1, pp. 41-48, 2009.

[12] A. Springler, G.-J. Vrubel, E. Mayer, G. Schatzmayr, and B. Novak, "Effect of Fusarium-derived metabolites on the barrier integrity of differentiated intestinal porcine epithelial cells (IPEC-J2)," Toxins, vol. 8, no. 11, article E345, p. 345, 2016.

[13] A. Romero, I. Ares, E. Ramos et al., "Mycotoxins modify the barrier function of Caco-2 cells through differential gene expression of specific claudin isoforms: protective effect of illite mineral clay," Toxicology, vol. 353-354, pp. 21-33, 2016.

[14] Y. Liu, J. Chang, P. Wang et al., "Effects of Saccharomyces cerevisiae on alleviating cytotoxicity of porcine jejunal epithelia cells induced by deoxynivalenol," AMB Express, vol. 9, no. 1, article 137, 2019.

[15] W. Guo, X. Gu, Y. Tong, X. Wang, J. Wu, and C. Chang, "Protective effects of mannan/ $\beta$-glucans from yeast cell wall on the deoxyniyalenol-induced oxidative stress and autophagy in IPEC-J2 cells," International Journal of Biological Macromolecules, vol. 135, pp. 619-629, 2019.

[16] J. W. Kluess, S. Kahlert, A. Kröber et al., "Deoxynivalenol, but not $E$. coli lipopolysaccharide, changes the response pattern of intestinal porcine epithelial cells (IPEC-J2) according to its route of application," Toxicology Letters, vol. 239, no. 3, pp. 161-171, 2015.

[17] P. M. Cano, J. Seeboth, F. Meurens et al., "Deoxynivalenol as a new factor in the persistence of intestinal inflammatory diseases: an emerging hypothesis through possible modulation of Th17-mediated response," PLoS One, vol. 8, no. 1, article e53647, 2013.

[18] J. Lucioli, P. Pinton, P. Callu et al., "The food contaminant deoxynivalenol activates the mitogen activated protein kinases in the intestine: Interest of ex vivo models as an alternative to in vivo experiments," Toxicon, vol. 66, pp. 31-36, 2013.

[19] X. Wang, Q. Liu, A. Ihsan et al., "JAK/STAT pathway plays a critical role in the proinflammatory gene expression and apoptosis of RAW264.7 cells induced by trichothecenes as DON and T-2 toxin," Toxicological Sciences, vol. 127, no. 2, pp. 412-424, 2012.

[20] J. Van De Walle, B. Romier, Y. Larondelle, and Y. J. Schneider, "Influence of deoxynivalenol on NF- $\kappa \mathrm{B}$ activation and IL-8 secretion in human intestinal Caco-2 cells," Toxicology Letters, vol. 177, no. 3, pp. 205-214, 2008.

[21] M. A. Bin-Umer, J. E. McLaughlin, M. S. Butterly, S. McCormick, and N. E. Tumer, "Elimination of damaged mitochondria through mitophagy reduces mitochondrial oxidative stress and increases tolerance to trichothecenes," Proceedings of the National Academy of Sciences of the United States of America, vol. 111, no. 32, pp. 11798-11803, 2014.

[22] J. Liu, L. Wang, X. Guo et al., "The role of mitochondria in T-2 toxin-induced human chondrocytes apoptosis," PLoS One, vol. 9, no. 9, article e108394, 2014.

[23] A. D. Frond, C. I. Iuhas, I. Stirbu et al., "Phytochemical characterization of five edible purple-reddish vegetables: anthocyanins, flavonoids, and phenolic acid derivatives," Molecules, vol. 24, no. 8, article E1536, 2019.
[24] O. Fadel, K. El Kirat, and S. Morandat, "The natural antioxidant rosmarinic acid spontaneously penetrates membranes to inhibit lipid peroxidation in situ," Biochimica et Biophysica Acta, vol. 1808, no. 12, pp. 2973-2980, 2011.

[25] S. J. Kim, J. Y. Um, S. H. Kim, and S. H. Hong, "Protective effect of rosmarinic acid is through regulation of inflammatory cytokine in cadmium-induced ototoxicity," The American Journal of Chinese Medicine, vol. 41, no. 2, pp. 391-404, 2013.

[26] M. Villalva, L. Jaime, E. Aguado, J. A. Nieto, G. Reglero, and S. Santoyo, "Anti-inflammatory and antioxidant activities from the basolateral fraction of Caco-2 cells exposed to a rosmarinic acid enriched extract," Journal of Agricultural and Food Chemistry, vol. 66, no. 5, pp. 1167-1174, 2018.

[27] G. Repetto, A. del Peso, and J. L. Zurita, "Neutral red uptake assay for the estimation of cell viability/cytotoxicity," Nature Protocols, vol. 3, no. 7, pp. 1125-1131, 2008.

[28] M. C. Smith, S. Madec, E. Coton, and N. Hymery, "Natural cooccurrence of mycotoxins in foods and feeds and their in vitro combined toxicological effects," Toxins, vol. 8, no. 4, p. 94, 2016.

[29] Y. Lei, Z. Guanghui, W. Xi et al., "Cellular responses to T-2 toxin and/or deoxynivalenol that induce cartilage damage are not specific to chondrocytes," Scientific Reports, vol. 7, no. 1, article 2231, 2017.

[30] M. J. Ruiz, P. Franzova, A. Juan-García, and G. Font, “Toxicological interactions between the mycotoxins beauvericin, deoxynivalenol and T-2 toxin in CHO-K1 cells in vitro," Toxicon, vol. 58, no. 4, pp. 315-326, 2011.

[31] M. J. Ruiz, P. Macáková, A. Juan-García, and G. Font, "Cytotoxic effects of mycotoxin combinations in mammalian kidney cells," Food and Chemical Toxicology, vol. 49, no. 10, pp. 27182724, 2011.

[32] A. S. Ficheux, Y. Sibiril, and D. Parent-Massin, "Co-exposure of Fusarium mycotoxins: In vitro myelotoxicity assessment on human hematopoietic progenitors," Toxicon, vol. 60, no. 6, pp. 1171-1179, 2012.

[33] P. A. Gentry, G. S. Bondy, and M. L. Ross, "Comparison of the inhibition of deoxynivalenol and T-2 toxin on bovine and porcine platelet function," Mycotoxin Research, vol. 4, no. 1, pp. 25-32, 1988.

[34] V. Vandenbroucke, S. Croubels, A. Martel et al., "The mycotoxin deoxynivalenol potentiates intestinal inflammation by Salmonella typhimurium in porcine ileal loops," PLoS One, vol. 6, no. 8, article e23871, 2011.

[35] E. Verbrugghe, V. Vandenbroucke, M. Dhaenens et al., “T-2 toxin induced Salmonella Typhimurium intoxication results in decreased Salmonella numbers in the cecum contents of pigs, despite marked effects on Salmonella-host cell interactions," Veterinary Research, vol. 43, no. 1, p. 22, 2012.

[36] P. Akbari, S. Braber, S. Varasteh, A. Alizadeh, J. Garssen, and J. Fink-Gremmels, "The intestinal barrier as an emerging target in the toxicological assessment of mycotoxins," Archives of Toxicology, vol. 91, no. 3, pp. 1007-1029, 2017.

[37] H. Vergauwen, S. Prims, J. Degroote et al., "In vitro investigation of six antioxidants for pig diets," Antioxidants, vol. 5, no. 4, article E41, 2016.

[38] T. Kishimoto, S. Akira, and T. Taga, "Interleukin-6 and its receptor: a paradigm for cytokines," Science, vol. 258, no. 5082, pp. 593-597, 1992.

[39] F. Sallusto and M. Baggiolini, "Chemokines and leukocyte traffic,” Nature Immunology, vol. 9, no. 9, pp. 949-952, 2008. 
[40] L. Y. M. Wan, P. C. Turner, and H. El-Nezami, "Individual and combined cytotoxic effects of Fusarium toxins (deoxynivalenol, nivalenol, zearalenone and fumonisins B1) on swine jejunal epithelial cells," Food and Chemical Toxicology, vol. 57, pp. 276-283, 2013.

[41] P. Kruber, S. Trump, J. Behrens, and I. Lehmann, "T-2 toxin is a cytochrome P450 1A1 inducer and leads to MAPK/p38- but not aryl hydrocarbon receptor-dependent interleukin-8 secretion in the human intestinal epithelial cell line Caco-2," Toxicology, vol. 284, no. 1-3, pp. 34-41, 2011.

[42] P. Liao, Y. Li, M. Li et al., "Baicalin alleviates deoxynivalenolinduced intestinal inflammation and oxidative stress damage by inhibiting NF- $\kappa \mathrm{B}$ and increasing mTOR signaling pathways in piglets," Food and Chemical Toxicology, vol. 140, article 111326, 2020.

[43] A. Zha, D. Yuan, Z. Cui et al., "The evaluation of the antioxidant and intestinal protective effects of baicalin-copper in deoxynivalenol-challenged piglets," Oxidative Medicine and Cellular Longevity, vol. 2020, Article ID 5363546, 13 pages, 2020.

[44] A. Zha, Z. Cui, M. Qi et al., "Dietary baicalin zinc supplementation alleviates oxidative stress and enhances nutrition absorption in deoxynivalenol challenged pigs," Current Drug Metabolism, vol. 21, no. 8, pp. 614-625, 2020.

[45] M. J. Gu, S. K. Song, I. K. Lee et al., "Barrier protection via tolllike receptor 2 signaling in porcine intestinal epithelial cells damaged by deoxynivalnol," Veterinary Research, vol. 47, no. $1,2016$.

[46] T. Suzuki, "Regulation of intestinal epithelial permeability by tight junctions," Cellular and Molecular Life Sciences, vol. 70, no. 4, pp. 631-659, 2013.

[47] Z. Qiang, Bioavailability and Metabolism of Botanical Constituents and Enhancement of Intestinal Barrier Function by Caffeic Acid Derivatives in Caco-2 Cells, [M.S. Thesis], Graduate Theses and Dissertations, Iowa State University, Iowa, U.S.A, 2011. 